\title{
Mecanismos De Combate À Desinformação: Uma Análise À Luz Da Comissão Interamericana De Direitos Humanos
}

\author{
Beatriz Pereira Junqueira* \\ Universidade Estadual do Norte do Paraná, Programa de Pós-Graduação em Direito, Jacarezinho-PR, \\ Brasil. \\ iD https://orcid.org/oooo-0oo1-6788-6991 \\ Paulo Henrique de Souza Freitas ** \\ Universidade Estadual do Norte do Paraná, Programa de Pós-Graduação em Direito, Jacarezinho-PR, \\ Brasil. \\ iD https://orcid.org/oooo-0003-0014-9887
}

Resumo: Valendo-se da pesquisa de natureza qualitativa, do método de abordagem dedutivo e das técnicas de pesquisa bibliográfica e documental, o artigo objetiva analisar os mecanismos de combate à desinformação à luz das recomendações da Comissão Interamericana de Direitos Humanos e do test tripartite desenvolvido pela jurisprudência interamericana. Concluiu-se que a informação falsa está incluída no âmbito de proteção jurídica conferido à liberdade de expressão, uma vez que a exigência de veracidade na informação tende a se degenerar em censura ao direito de expressar livremente opiniões, ideias e informações; e uma eventual criminalização das fake news, assim como a responsabilização dos provedores, constituem restrições extremamente perigosas à liberdade de expressão e ilegítimas, posto que não cumprem os requisitos básicos fixados pelo test tripartite. Depreendeu-se, por fim, que as recomendações realizadas pela Comissão Interamericana aos Estados nacionais são no sentido de promoção de medidas positivas como a alfabetização midiática, a conscientização da população e o incentivo às plataformas de checagem de fatos, uma vez que representam alternativas promissoras no combate à desinformação ao passo que não acarretam restrições ou supressões à liberdade de expressão.

Palavras-chave: Notícia falsa. Liberdade de expressão. Alfabetização midiática. Conscientização. Checagem de fatos.

* Mestranda em Ciência Jurídica pela Universidade Estadual do Norte do Paraná - UENP -

Jacarezinho/PR. E-mail: beatriz-p-j@hotmail.com

** Doutor em Direito Comercial pela Pontifícia Universidade Católica de São Paulo (2003). Professor da Instituição Toledo de Ensino (ITE) - Bauru. Professor da Universidade Estadual do Norte do Paraná (UENP) - Faculdade Estadual de Direito do Norte Pioneiro - (FUNDINOPI). E-mail: henrique@mpse.mp.br

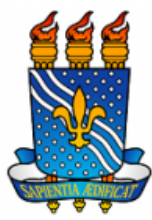

UNIVERSIDADE FEDERAL DA PARAÍBA

Programa de Pós-Graduação em Ciências Jurídicas

DOI: https://doi.org/ 10.22478/ufpb.1678-2593.2021v20n43.54652 


\title{
Mecanismos De Combate À Desinformação: Uma Análise À Luz Da Comissão Interamericana De Direitos Humanos
}

\author{
Beatriz Pereira Junqueira
}

Paulo Henrique de Souza Freitas

\section{INTRODUÇÃO}

A liberdade de expressão é um direito humano e fundamental, essencial à garantia e exercício dos demais direitos humanos, e da própria democracia. Destarte, por consequência lógica e necessária, sempre que houver risco de restrição ou supressão ao livre fluxo de ideias e informações, todos os outros direitos humanos, assim como a tão cara democracia, estarão em perigo.

Se assim o é, merece atenção todo fato jurídico tendente a esvaziar a esfera de proteção jurídica conferida à liberdade de expressão, como é o caso das leis de combate às fake news que, sob o pretexto de manutenção da ordem, da democracia e da saúde pública, ameaçam o pleno exercício da liberdade de expressão, informação e imprensa.

O hodierno potencial de disseminação das fake news, bem como sua onerosa repercussão social, tornaram-se ainda mais evidentes com a avalanche de desinformação que acompanhou a pandemia de COVID-19, reacendendo os debates acerca da regulamentação das notícias falsas no Direito brasileiro. O fenômeno da desinformação é preocupante e exige resposta, mas ainda não há 
um consenso sobre quais medidas devem ser adotadas para o para o enfrentamento do problema.

São diversos os mecanismos que vêm sendo propostos pelas autoridades e comunidades acadêmica e científica com a finalidade de combater a desinformação. Muitos deles, inclusive, com enorme potencial de esvaziamento da proteção jurídica conferida à liberdade de expressão, como é o caso da responsabilização civil ou penal de quem de publica, divulga ou compartilha notícias falsas, e da responsabilização objetiva dos provedores de aplicação pelos conteúdos publicados por terceiros.

Diante de tal cenário, objetiva-se, à luz das recomendações da Comissão Interamericana de Direitos Humanos e do test tripartite desenvolvido pela Jurisprudência Interamericana, avaliar os mecanismos de combate à desinformação, buscando identificar quais deles apresentam riscos à liberdade de expressão e quais se mostram aptos a combater a pandemia de desinformação sem acarretar na restrição ou supressão da liberdade de expressão.

Para tanto, apresentar-se-á, num primeiro momento, a conceituação dos termos essenciais à compreensão do tema, como fake news, desinformação, desinfodemia e pós-verdade. Em seguida, abordar-se-á o direito à liberdade de expressão, com a finalidade de investigar se seria a verdade o seu limite imanente, ou seja, se estaria a informação errônea fora do âmbito de proteção jurídica conferida a esse direito fundamental e humano de expressar livremente opiniões, pensamentos e informações, valendo-se da interpretação conferida pela Comissão Interamericana de Direitos Humanos ao artigo 13 do Pacto da San José da Costa Rica. Por fim, ocupar-se-á de analisar a linha tênue que se estabelece entre combate às fake news e censura, com a finalidade de averiguar, conforme o entendimento da $\mathrm{CIDH}$, quais mecanismos constituem restrições ilegítimas à liberdade de expressão, e quais representam alternativas viáveis para reduzir a desinformação na mesma medida em que se eleva a proteção conferida à liberdade de expressão. 


\section{ERA DA PÓS-VERDADE E DESINFORMAÇÃO}

A era digital trouxe, inegavelmente, grandes avanços em diversos aspectos da vida humana. Esta nova era colou nas mãos dos cidadãos, de modo mais democrático e facilitado, uma das ferramentas mais relevantes para o exercício da cidadania, aquela que lhes permite expressar livremente a sua opinião, protesto ou inconformidade em relação a qualquer parecer, preponderantemente social e político: a liberdade de expressão (MORALES, 2018, p. 17).

Como destaca André de Godoy Fernandes (2009, p. 316), a internet, por ser uma mídia convergente, de livre acesso e uso geral do público, tem a capacidade de promover a difusão de informações, que antes eram transmitidos exclusivamente por veículos de comunicação tradicionais (como televisão, rádio, jornal, etc.), de forma mais fácil, barata e democrática. A internet, segundo o autor, "permite uma distribuição mais igualitária das oportunidades de participação na esfera pública”.

Não foi outra a conclusão a que chegou Carlos F. B. Bentivegna (2020, p. 93) ao afirmar que "após o advento da internet, principalmente, pôde-se notar significativo incremento no exercício da liberdade de expressão, visto que o acesso à difusão de ideias quedouse facilitado e democratizado”.

Ao converter milhões de pessoas que eram receptoras passivas de informação em participantes ativos do debate público, a internet representa uma das tecnologias que mais tem potencializado o exercício da liberdade de expressão (CIDH, 2019, p. 13).

Não apenas a expressão de pensamentos e opiniões ganhou espaço na internet, mas também as notícias. As redes sociais representam hoje o maior veículo de comunicação de notícias existente, assumindo o lugar no pódio que por muitas décadas pertenceu à imprensa tradicional, como rádio, jornal e televisão. 
Entretanto, a era digital também tem seu lado negativo: a desinformação, assim como as ofensas aos direitos de personalidade, como honra, imagem e privacidade, se dissemina facilmente na internet, e com uma velocidade impressionante, para não dizer assustadora.

Cabe ressaltar, entretanto, que a grande responsável pela pandemia de desinformação não é a tecnologia, mas o uso que se faz dela. Até porque, a tecnologia não determina a sociedade, muito pelo contrário, é a "sociedade é que dá forma à tecnologia de acordo com as necessidades, valores e interesses das pessoas que utilizam as tecnologias" (CASTELLS, 2005).

Mas, afinal, o que é desinformação, notícia falsa e pós-verdade, e de que forma tais conceitos estão relacionados?

Pós-verdade e fake news são dois termos que ganharam ampla notoriedade no final de 2016, especialmente em decorrência no contexto político mundial marcado pela intensa divulgação de notícias falsas relacionadas sobretudo ao Brexit (como foi apelidada a resolução que determinou a saída do Reino Unido da União Europeia) e à eleição de Donald Trump para presidente dos Estados Unidos (GENESINI, 2018).

Logo em seguida, "pós-verdade” foi eleita pelo Dicionário Oxford como a palavra do ano, em razão do crescimento elevado do seu uso durante 2016. Segundo o próprio dicionário britânico, o termo está "relacionado ou denota circunstâncias em que os fatos objetivos são menos influentes na formação da opinião pública do que apelos a emoções ou crenças pessoais" (2019, s/p¹).

Já conforme Carlos Eduardo Lins da Silva (2018), “o termo pósverdade, carregado de grande carga simbólica, talvez não seja o mais adequado para explicar o fenômeno que enfrentamos”. Isto porque a

${ }^{1}$ Tradução do autor. No original: "Relating to or denoting circumstances in which objective facts are less influential in shaping public opinion than appeals to emotion and personal belief". 
verdade é uma palavra grandiosa demais, e com elevado poder ideológico e metafísico que há séculos desafia a compreensão humana.

Dessa forma, para ele, a expressão pós-fato, criada em 2008 pelo sociólogo e jornalista Farhad Manjoo, é mais adequada ao problema, uma vez que é menos pretensioso e mais simples tentar distinguir o fato da ficção do que diferenciar a verdade da mentira. " $E$ mais possível constatar e comprovar fatos do que verdades" (SILVA, 2018).

Tal concepção, no entendimento de Silvio Genesini (2018, p. 05), se aproxima da verdade factual de Hannah Arendt, a qual foi definida, no ensaio "Verdade e Política" publicado na revista New Yorker em 1967, como a parcela da verdade que é baseada em fatos e pode ser comprovada e certificada experimentalmente. Para o autor, fora do estrito âmbito dos fatos, "a verdade, quase sempre, é subjetiva e não conhecível”. Nunca houve um mundo no qual a verdade existia e era objetiva.

Como se percebe, pois, não se trata de verdade versus mentira, mas de fatos versus não fatos. De todo modo, talvez a severa diferenciação conceitual não seja assim tão relevante para a compreensão do tema em voga, já que, inegavelmente, tudo aquilo que foge da realidade dos fatos costuma ser taxado como "mentira". Mas, fica aqui essa ressalva.

Veja, o que mudou com o advento da era digital não foi o surgimento das notícias falsas ou dos não fatos, enfim, da mentira. A mentira sempre existiu. O que mudou, segundo Vinicius B. Fortes e Wellington A. Baldissera (2019, p. 378), com o acesso massivo da população às tecnologias, redes sociais, aplicativos de mensagens, entre outros, foi a velocidade com que as informações se propagam, tanto as verídicas quanto as enganosas e manipuladoras.

Tal velocidade de disseminação é ainda mais potencializada quando da atuação de bots (softwares que atuam como verdadeiros robôs concebidos para simular ações humana de forma automatizada e repetitiva) ou ciborgues (pessoas que atuam com auxílio de softwares). 
Percebe-se, assim, que na era da pós-verdade, marcada por uma sociedade que prefere a ficção aos fatos, e nega tudo aquilo que não lhe convém $^{2}$, o potencial destrutivo das fake news ganha especial relevo.

O termo fake news, conforme Paul Levinson (2017, p. 11), pode ser definido como notícias falsas, em que as falsidades aparecem por intenção deliberada, e não por acidente ou erro. Semelhante é a definição realizada por Hunt Allcott e Matthew Gentzkow (2017, p. 213), segundo a qual fake news são notícias intencional e verificavelmente falsas, capazes de enganar os leitores.

Por outro lado, de acordo com Diogo Rais (2018), a expressão fake news é um paradoxo em si mesma, posto que se algo é notícia, por sua própria natureza, não pode ser falso; e se é falso, não pode ser notícia. Nesse sentido, ele propõe que uma boa tradução para o termo não seria "notícia falsa", mas "notícia fraudulenta", porque a denominada fake news nem sempre é falsa, podendo abranger tanto o conteúdo falso no contexto verdadeiro, como o conteúdo verdadeiro no contexto falso; e nem sempre é pejorativa, podendo ser, inclusive, elogiosa.

Um exemplo de conteúdo verdadeiro em um contexto falso foi a foto de um vagão lotado no transporte público de São Paulo, cuja legenda afirmava que a aglomeração era resultado do rodízio ampliado de veículos na capital paulista, determinado pelo Prefeito Bruno Covas como uma forma de aumentar o isolamento social durante a Pandemia. A foto era verdadeira, porém antiga, e não tinha qualquer relação com a situação narrada na legenda, conforme demonstrado no site da Agência Lupa (2020), primeira agência de fact-checking do Brasil, vinculada à Folha de São Paulo.

De forma semelhante, Ulrich Richter Morales (2018, p. 28) escreve que notícia falsa é aquela que não é (notícia), ao passo que

${ }^{2}$ Conforme Renê Morais da Costa Braga (2018, p. 210-211), essa tendência humana de buscar e dar maior atenção às informações que ratificam as suas convicções pessoais é denominada pela psicologia de "viés de confirmação" (ou confirmation bias, na expressão em inglês). 
carece de verdade e é contrária à realidade dos fatos. Em simples palavras, uma mentira, uma narrativa falsa travestida de notícia.

Ressalte-se, outrossim, que embora os termos "notícia falsa" e "desinformação" sejam comumente empregados como sinônimos, conforme o Relatório do Grupo Independente de Alto Nível da Comissão Europeia sobre Notícias Falsas e Desinformação Online (HLEG, 2018), eles não possuem o mesmo significado.

De acordo com o referido Relatório, desinformação "inclui todas as formas de informações falsas, imprecisas ou enganosas, projetadas, apresentadas e promovidas para causar intencionalmente danos públicos ou obter fins lucrativos”. Não abrange, por sua vez, as formas de expressão já ilegais - como difamação, calúnia, injúria, incitação ao ódio, violência, entre outros - nem as distorções deliberadas, mas não enganosas, que se caracterizam como sátira ou paródia.

Ainda, consoante o HLEG (2018), o termo "fake news", além de inadequado (insuficiente) para descrever o fenômeno, cuja definição é melhor proporcionada pelo termo "desinformação", é enganoso, uma vez que foi apropriado por alguns políticos que usam o termo para descredibilizar notícias que lhe são desagradáveis, transformando-o em uma arma com a qual interferem na circulação de informações, atacando e prejudicando a mídia séria e independente.

Essa distorção do significado das fake news também foi apontada por Ricardo Gutiérrez, no Seminário Internacional sobre Fake News e Eleições (2019, p. 28). Segundo ele, é preferível a utilização de expressões mais neutras, como desinformação, informação equivocada ou transtorno de informação, pois o "diabo está nos detalhes", e a expressão fake news tem sido majoritariamente utilizada por alguns políticos para culpar a mídia e os jornalistas, de modo a enfraquecê-los como um poder contrário.

Quanto aos fins lucrativos da desinformação, Carlos Eduardo Lins da Silva (2018) salienta que a falsidade se tornou uma fonte de renda consideravelmente lucrativa. $\mathrm{E}$ adverte que, atualmente, há uma "industrialização da notícia falsa com o objetivo de fazer dinheiro com 
anúncios que são alocados por instrumentos regidos por algoritmos que premiam sites com maior visibilidade, acesso, compartilhamento". Nesses casos, a notícia falsa é forjada com o simples objetivo de lucro.

Nesse contexto de desinformação, insere-se, ainda, a denominada "deepfake" ou falsificação profunda, em tradução literal. Essa nova tecnologia de falsificação - cujo nome decorre da junção dos termos "deep learning", de aprendizado profundo (baseado no acúmulo de conhecimentos por determinado banco de dados) e "fake", de falso (RAIS; SALES, 2020, p. 28) - compreende vídeos e áudios falsos, extremamente verossímeis e que, por tal razão, são especialmente perigosos, com potencial de "minar a verdade, confundir os espectadores e falsificar com precisão a realidade” (HASAN; SALAH, 2019, p. 415963).

As deepfakes são desenvolvidas por inteligência artificial com base na técnica de aprendizado profundo, no processamento de imagens e em softwares de montagem. Utilizando-se de amostras de voz e imagens de uma certa pessoa, um algoritmo é capaz de fabricar um vídeo ou áudio com discurso falso, mas com entonação e timbre voz praticamente idênticos aos reais, o que torna cada vez mais árdua a tarefa de distinguir a realidade da manipulação (RAIS; SALES, 2020, p. 29).

Essa versão inovadora de desinformação consegue, pois, alterar a realidade dos fatos, atribuindo inigualável feição de veracidade até à mais absurda mentira, criando uma realidade na qual não se pode mais acreditar naquilo que os olhos e ouvidos testemunham.

Um outro termo que merece destaque é "Desinfodemia", cunhado pela Unesco (2020, p. 02) para designar a disseminação massiva de desinformação que acompanhou a pandemia de COVID19. Segundo o relatório elaborado pela Organização, “a desinformação do COVID-19 cria confusão sobre a ciência médica com impacto

3 Tradução do autor. No original: "Deepfake vídeos are dangerous, and can have the potential to undermine truth, confuse viewers and accurately fake reality". 
imediato em todas as pessoas do planeta e em todas as sociedades. É mais tóxico e mais mortal do que a desinformação sobre outros assuntos".

Conforme matéria publicada por Plínio Lopes, em 11/06/2020, na Revista Piauí, as publicações falsas ou enganosas sobre remédios sem efeito comprovado contra Covid-19 representam um terço das verificações realizadas pelo Comprova em maio de 20204 (LOPES, 2020).

Extrai-se, portanto, que fake news não representa o termo mais adequado para descrever o fenômeno da desinformação que, por sua vez, é mais amplo e engloba o primeiro. A desinformação abarca tanto as informações falsas, mentirosas e pejorativas em um contexto verdadeiro, quanto as informações verdadeiras e elogiosas em um contexto falso.

Contudo, dada a ampla notoriedade do termo fake news, considerando que diversos atores da sociedade acadêmica e científica a definem nos exatos termos da desinformação, e considerando, ainda mais, que em toda fake news faz-se presente o elemento do engano e da fraude, utilizar-se-á, nesta pesquisa, o termo notícia falsa como se sinônimo fosse de notícia fraudulenta e desinformação.

Fato é que a desinformação "é um fenômeno tóxico para a informação de qualidade5 com consequências cada vez mais imprevisíveis" (DUCH, 2018), e cujo impacto se estende a todos os âmbitos da sociedade, razão pela qual autoridades e estudiosos de todo o mundo estão em busca de mecanismos aptos a combatê-la, sem gerar, contudo, supressão ou restrição à liberdade de expressão.

\footnotetext{
4 O Projeto Comprova é uma coalisão que reúne 28 veículos de comunicação, dentre eles Revista Piaú, Folha de São Paulo, Estadão, Uol, Nexo, O Povo, Exame e A Gazeta (COMPROVA, 2020).

5 Relevante destacar que há quem acredite, como Silvio Genesini (2018), que a "pósverdade" é uma notícia falsa, e que as fake news não possuem tanto potencial de manipular a realidade, tampouco de enganar as pessoas, uma vez que elas apenas reforçariam convicções e preconceitos já interiorizados pelos indivíduos.
} 


\section{A VERDADE COMO LIMITE INERENTE À LIBERDADE DE EXPRESSÃO?}

A liberdade de expressão é um direito humano fundamental de suma importância para o exercício dos demais direitos humanos e da própria democracia. Como destaca Toby Mendel e Eve Salomon (2011, p. 10), "sempre que o livre fluxo de informações e ideias não for permitido, outros direitos humanos, assim como a própria democracia, estarão em perigo". Tamanha é a relevância da liberdade de expressão que sua proteção jurídica encontra amparo nos principais documentos internacionais sobre direitos humanos, assim como nas Constituições dos Estados Nacionais.

Conforme sustenta Luis Roberto Barroso (BRASIL, 2018, p. 56), este lugar privilegiado que a liberdade de expressão ocupa na ordem jurídica nacional e internacional decorre dos próprios fundamentos filosóficos da sua proteção, dos quais se destacam cinco principais:

(i) a função essencial que desempenha para a democracia, ao assegurar um livre fluxo de informações e a formação de um debate público robusto e irrestrito, condições essenciais para a tomada de decisões da coletividade e para o autogoverno democrático; (ii) a dignidade humana, ao permitir que indivíduos possam exprimir de forma desinibida suas ideias, preferências e visões de mundo, bem como terem acesso às dos demais indivíduos, fatores essenciais ao desenvolvimento da personalidade, à autonomia e à realização existencial; (iii) a busca da verdade, ao contribuir para que ideias só possam ser consideradas ruins ou incorretas após o confronto com outras ideias; (iv) a função instrumental ao gozo de outros direitos fundamentais, como o de participar do debate público, o de reunir-se, de associar-se, e o de exercer direitos políticos, dentre outros; e, conforme destacado anteriormente (v) a preservação da cultura e da história da sociedade, por se tratar de condição para a criação e o avanço do conhecimento e para a formação e preservação do patrimônio cultural de uma nação.

Pois bem. No âmbito do sistema global de proteção dos direitos humanos, a liberdade de expressão encontra-se resguardada no artigo 
19 da Declaração Universal dos Direitos Humanos (DUDH), proclamada pela Assembleia Geral das Nações Unidas em 1948, e considerada a declaração internacional mais importante em matéria de direitos humanos; bem como no artigo 19 do Pacto Internacional de Direitos Civis e Políticos (PIDCP), promulgado também pela Assembleia Geral das Nações Unidas em 1966, e que entrou em vigor no Brasil em julho de 1992.

Ainda assim, o direito à liberdade de expressão encontra amparo nos três sistemas regionais de proteção dos direitos humanos, mediante previsão no artigo 9 da Carta Africana de Direitos Humanos e dos Povos; no artigo 10 da Convenção Europeia de Direitos Humanos; e no artigo 13 da Convenção Americana sobre Direitos Humanos (Pacto da San Jose da Costa Rica - ratificado pelo Brasil em setembro de 1992). Este último, dispõe que:

1. Toda pessoa tem direito à liberdade de pensamento e de expressão. Esse direito compreende a liberdade de buscar, receber e difundir informações e ideias de toda natureza, sem consideração de fronteiras, verbalmente ou por escrito, ou em forma impressa ou artística, ou por qualquer outro processo de sua escolha.

2. O exercício do direito previsto no inciso precedente não pode estar sujeito a censura prévia, mas a responsabilidades ulteriores, que devem ser expressamente fixadas pela lei e ser necessárias para assegurar: a) o respeito aos direitos ou à reputação das demais pessoas; ou b) a proteção da segurança nacional, da ordem pública, ou da saúde ou da moral públicas.

3. Não se pode restringir o direito de expressão por vias ou meios indiretos, tais como o abuso de controles oficiais ou particulares de papel de imprensa, de frequências radioelétricas ou de equipamentos e aparelhos usados na difusão de informação, nem por quaisquer outros meios destinados a obstar a comunicação e a circulação de ideias e opiniões.

4. A lei pode submeter os espetáculos públicos a censura prévia, com o objetivo exclusivo de regular o acesso a eles, para proteção moral da infância e da adolescência, sem prejuízo do disposto no inciso 2.

5. A lei deve proibir toda propaganda a favor da guerra, bem como toda apologia ao ódio nacional, racial ou religioso que constitua incitação à discriminação, à hostilidade, ao crime ou à violência (grifo nosso). 
Ademais, referido direito tem expressa previsão constitucional nos artigos $5^{\circ}$, incisos IV, IX e XIV, e 220 da Carta Magna de 1988, cuja redação está oportunamente transcrita abaixo:

Artigo $5^{\circ}$. Todos são iguais perante a lei, sem distinção de qualquer natureza, garantindo-se aos brasileiros e aos estrangeiros residentes no País a inviolabilidade do direito à vida, à liberdade, à igualdade, à segurança e à propriedade, nos termos seguintes: IV - é livre a manifestação do pensamento, sendo vedado o anonimato; IX - é livre a expressão da atividade intelectual, artística, científica e de comunicação, independentemente de censura ou licença; XIV - é assegurado a todos o acesso à informação e resguardado o sigilo da fonte, quando necessário ao exercício profissional.

Artigo 220. A manifestação do pensamento, a criação, a expressão e a informação, sob qualquer forma, processo ou veículo não sofrerão qualquer restrição, observado o disposto nesta Constituição. $\$ 2^{\circ}$ É vedada toda e qualquer censura de natureza política, ideológica e artística.

Da análise literal da gama de dispositivos acima mencionados, pode-se inferir que a liberdade de pensamento e expressão implica, portanto, na liberdade de procurar, receber e difundir informações, opiniões e ideias de qualquer natureza, por qualquer meio, e independentemente de considerações de fronteiras, sendo vedada qualquer tipo de censura prévia, bem como a restrição da expressão por vias ou meios indiretos, sendo certo que a responsabilização ulterior será admitida desde que haja expressa previsão legal.

Nas palavras de Carlos F. B. Bentivegna (2020, p. 93), o direito à liberdade de expressão, em seu sentido lato, abrange a (1) exteriorização de pensamentos, (2) a exposição do produto da atividade artística, intelectual, científica ou de comunicação, e também (3) o direito de informar e de ser informado sobre os fatos não abrangidos por uma causa legítima de sigilo.

São, assim, três os direitos abarcados pela "liberdade de expressão": a liberdade de expressão propriamente dita, a liberdade de informação e a liberdade de imprensa. Conforme a conceituação realizada por Luis Roberto Barroso (2004, p. 18-19), tem-se que a liberdade de expressão destina-se a tutelar o direito de externar ideias, opiniões e juízos de valor, isto é, qualquer manifestação do pensamento humano. A liberdade de informação, por seu turno, 
abarca o direito individual de comunicar livremente fatos, e o direito difuso de ser deles informado. Por fim, a liberdade de imprensa consiste no direito reconhecido, ou melhor, conquistado pelos meios de comunicação em geral de comunicarem fatos e ideias, o que envolve tanto a liberdade de informação como a de expressão.

Ademais, como salientam Toby Mendel, Ángel G. Castillejo e Gustavo Gómez (2017, p. 16), o direito à liberdade de expressão é multidimensional, porque não inclui apenas o direito de quem se expressa, mas também de quem escuta, de buscar e receber informações e ideias. Semelhante é o entendimento da Corte Interamericana de Direitos Humanos no que diz respeito à natureza dual da liberdade de expressão, conforme Opinião Consultiva OC-5/85 de 13 de novembro de 1985 . Veja:

30. (...). Quando se restringe ilegalmente a liberdade de expressão de um indivíduo, não é apenas o direito desse indivíduo que está sendo violado, mas também o direito de todos a receber informações e ideias, de onde resulta que o direito protegido pelo artigo 13 tem um alcance e um caráter especial. Essas são as duas dimensões da liberdade de expressão. Em enfeito, esta requer, por um lado, que ninguém seja arbitrariamente restringido ou impedido de manifestar seu pensamento e representa, portanto, um direito de cada indivíduo; mas também implica, por outro lado, um direito coletivo de receber qualquer informação e conhecer a expressão do pensamento alheio ${ }^{6}$.

Consequentemente, o direito à liberdade de expressão implica, para os Estados, obrigações negativas e positivas. As obrigações negativas têm por condão impedir que o pleno exercício da expressão por parte de toda e qualquer pessoa sofra ingerências ou restrições estatais. As obrigações positivas, por sua vez, visam obrigar o Estado a adotar medidas para promover um ambiente aberto ao livre fluxo de

${ }^{6}$ Tradução do autor. No Original: "Por tanto, cuando se restringe ilegalmente la libertad de expresión de un individuo, no sólo es el derecho de ese individuo el que está siendo violado, sino también el derecho de todos a "recibir" informaciones e ideas, de donde resulta que el derecho protegido por el artículo 13 tiene un alcance y un carácter especiales. Se ponen así de manifiesto las dos dimensiones de la libertad de expresión. En efecto, ésta requiere, por un lado, que nadie sea arbitrariamente menoscabado o impedido de manifestar su propio pensamiento y representa, por tanto, un derecho de cada individuo; pero implica también, por otro lado, un derecho colectivo a recibir cualquier información y a conocer la expresión del pensamento ajeno". 
informações e ideias na sociedade (MENDEL; CASTILLEJO; GÓMEZ, 2017, p. 15).

Nessa perspectiva, garantir a liberdade de expressão significa um compromisso efetivo com a democracia, com a promoção do debate público e com a garantia do igual acesso aos meios de comunicação. É assegurar, portanto, que todos possuam não apenas a possibilidade de se expressar livremente, mas proporcionar meios para que as barreiras ao ambiente comunicativo sejam verdadeiramente superadas (PINTO, 2015, p. 167).

A princípio, conforme expresso no Marco Jurídico Interamericano sobre o Direito à Liberdade de Expressão, todas as formas de discurso são protegidas pelo direito à liberdade de expressão, independentemente do seu conteúdo. Significa que a liberdade de expressão deve ser garantida inclusive para a difusão de ideias e informações que ofendem, chocam, inquietam, ou perturbam, pois “assim o exigem o pluralismo, a tolerância e o espírito de abertura, sem os quais uma sociedade democrática não existe" (CIDH, 2014, p. 09-10).

Alguns discursos, contudo, estão excluídos do âmbito de cobertura dessa liberdade, em virtude das proibições previstas no direito internacional dos direitos humanos, quais sejam: a propaganda de guerra e a apologia ao ódio nacional, racial ou religioso que constitua incitação à discriminação, à hostilidade, ao crime ou à violência; a incitação direta e pública ao genocídio; e a pornografia infantil (CIDH, 2014, p. 19-20).

Quanto aos discursos albergados pela liberdade de expressão, considerando que tal direito não é absoluto, o Marco jurídico admite, excepcionalmente, a possibilidade de restrições, desde que cumpridos três requisitos cumulativos, que compõe o denominado test tripartite. $\mathrm{O}$ teste foi desenvolvido pela jurisprudência interamericana para controlar a legitimidade das restrições e determina que:

(1) a restrição deve ter sido definida de forma precisa e clara por meio de uma lei formal e material, (2) a restrição deve se orientar à realização de objetivos imperiosos 
autorizados pela Convenção Americana, e (3) a restrição deve ser necessária em uma sociedade democrática para o sucesso dos imperiosos fins buscados; estritamente proporcional à finalidade buscada; e idônea para alcançar o imperioso objetivo que procura realizar (CIDH, 2014, p. 23).

O Marco jurídico reforça a necessidade de as normas restritivas serem redigidas nos termos mais claros e preciso possíveis, uma vez que "as normas vagas, ambíguas, amplas ou abertas, por sua simples existência, dissuadem a expressão de informações e opiniões pelo medo de sanções e podem levar a interpretações judiciais que restringem indevidamente a liberdade de expressão” (CIDH, 2014, p. 24).

Quando se trata de restrição imposta por norma penal, há ainda, conforme a Corte Interamericana, em sentença proferida no Caso Usón Ramírez Vs Venezuela (2009, p. 16), o dever de satisfazer o princípio da estrita legalidade, que se concretiza mediante a utilização de termos estritos e unívocos, que delimitem claramente as condutas puníveis e seus elementos, além de explicitar os comportamentos não puníveis ou condutas ilícitas sancionáveis com medidas não penais.

De todo modo, as restrições, para serem compatíveis com a Convenção Americana, devem ser excepcionais; não podem equivaler à censura (devendo ser estabelecidas mediante responsabilidades ulteriores à própria expressão); não podem ser discriminatórias nem produzir efeitos discriminatórios; e não podem ser impostas por meio de mecanismos indiretos (CIDH, 2014, p. 29).

Uma coisa é certa: a farta proteção jurídica conferida à liberdade de expressão não implica na "imunidade de seu titular em relação às consequências geradas por um eventual agravo a terceiros que o abuso deste direito venha a causar (BENTIVEGNA, 2020, p. 93). Mas, deve-se frisar que qualquer restrição à manifestação do pensamento só é aceitável se posterior à própria expressão. Ou seja, não se restringe a expressão antes de sua manifestação, que pode ser exercida livremente, resguardada a possibilidade de posterior sanção ao abuso desse direito. 
No dizer de Taís Gasparian, no Seminário Internacional sobre Fake News e Eleições (2019, p. 79), "O Supremo Tribunal Federal tem sido o órgão catalisador dessa premissa de que qualquer controle que se faça à liberdade de expressão é posterior à própria expressão". Assim, não haveria de fato um controle à liberdade de expressão, mas, em verdade, um controle posterior daquilo que gerou determinada ofensa.

Como exemplo de restrições impostas à liberdade de expressão no Direito brasileiro, tem-se: a vedação do anonimato (artigo $5^{\circ}, \mathrm{IV}$, $\mathrm{CF} / 88$ ); o direito de resposta (artigo $5^{\circ}, \mathrm{V}, \mathrm{CF} / 88$ ); o dever de respeitar a intimidade, a vida privada, a honra e a imagem das pessoas, sob pena de indenização por dano moral, material e à imagem (artigo $5^{\circ}, \mathrm{X}, \mathrm{CF} / 88$ ); a classificação indicativa de diversões públicas e de programas de rádio e televisão (artigo 21, XVI, CF/88); e as restrições à propaganda comercial de tabaco, bebidas alcoólicas, agrotóxicos e terapias (artigo 220, $\S 4^{\circ}, \mathrm{CF} / 88$ ); e as restrições da divulgação relativa à criança ou adolescente a que se atribua ato infracional (artigos 143 e 247, ECA).

Citam-se, ainda, os crimes contra a honra (calúnia, difamação e injúria) e o crime de denunciação caluniosa (artigos 138, 139, 140 e 339, CP); os crimes contra a honra e de denunciação caluniosa eleitoral, além do crime que pune a divulgação de fatos inverídicos sobre partidos políticos ou candidatos para influenciar o eleitorado (artigo 323 e seguintes, $\mathrm{CE}$ ); crimes de difamação, calúnia e propaganda discriminatória ou de guerra, entre outros, previstos na Lei de Segurança Nacional (Lei $n^{\circ} 7.170 / 83$ ), bem como o disposto na Lei de Racismo (Lei $\mathrm{n}^{\circ}$ 7.716/1989 - que impõe sanções para a incitação à discriminação ou preconceito de raça, cor, etnia, religião ou procedência nacional).

Uma vez que a expressão configurar ato ilícito, poderá ser determinada, mediante ordem judicial, a sua exclusão da rede, sendo certo que somente haverá possibilidade de responsabilização civil dos provedores de aplicação por danos decorrentes de conteúdo gerado 
por terceiros se, após ordem judicial específica, não forem tomadas as providências para indisponibilizar o conteúdo apontado como infringente, conforme dispõe o artigo 19 do Marco Civil da Internet (Lei $\left.{ }^{\circ} 12.965 / 14\right)^{7}$.

Há uma exceção prevista no artigo 21 do Marco Civil da Internet que "trata da possibilidade de um conteúdo ofensivo ser removido mediante a simples notificação por parte da vítima, não havendo, portanto, a necessidade de se recorrer ao poder judiciário para alcançar esta finalidade". E em casos como esses, de violação da intimidade sexual de alguém, a possibilidade de remoção do conteúdo independentemente de ordem judicial é extremamente positiva, visto que minimiza consideravelmente o impacto da conduta lesiva (NEVES; WALDMAN, 2020, p. 22-23).

De todo modo, apenas a responsabilização ulterior por eventual abuso do direito pode ser admitida, desde que expressamente prevista em lei, sendo certo que nenhuma forma de censura prévia ou de restrição indireta ao pleno exercício da liberdade de expressão será tolerada, por expressa previsão no artigo 13 do Pacto de San José da Costa e Rica e no artigo 220 da Constituição Federal de 1988.

A proteção quase obsessiva das liberdades de imprensa, informação e expressão pela Constituição de 1988, e essa repulsa escancarada à censura visam nitidamente evitar a repetição dos erros de um passado sombrio e ainda muito recente na história brasileira: o regime militar. Como afirmou Luis Roberto Barroso, no julgamento da Reclamação Constitucional $\mathrm{n}^{\circ}$ 22328/RJ (BRASIL, 2018, p. 09), a liberdade de expressão no Brasil viveu uma história acidentada:

7Ressalta-se haver pendência na discussão acerca da constitucionalidade ou não do referido artigo 19 ( $\mathrm{RG} \mathrm{n}^{\circ}$ 987/STF) e sobre o dever dos provedores de tornar indisponível o conteúdo ofensivo, sem determinação judicial, ante a ausência de disposição legal na época anterior ao Marco Civil da Internet ( $R G n^{\circ}$ 553/STF). A audiência pública designada para 23 de março de 2020, na qual pretendia-se discutir sobre "i) o regime de responsabilidade de provedores de aplicativos ou de ferramentas de internet por conteúdo gerado pelos usuários, e ii) a possibilidade de remoção de conteúdos que possam ofender direitos de personalidade, incitar o ódio ou difundir notícias fraudulentas a partir de notificação extrajudicial”, foi suspensa ante a Pandemia de COVID-19. 
Apesar de prevista expressamente em todas as Constituições, desde 1824, ela é marcada pelo desencontro entre o discurso oficial e o comportamento do Poder Público, pela distância entre intenção e gesto. Em nome da religião, da segurança pública, do anticomunismo, da moral, da família, dos bons costumes e outros pretextos, a história brasileira na matéria tem sido assinalada pela intolerância, pela perseguição e pelo cerceamento da liberdade.

Por tal razão, busca-se, agora, a proteção efetiva da liberdade de expressão e a consequente vedação à censura prévia. Entende-se por censura prévia "o controle e veto da informação antes que esta seja difundida, impedindo tanto ao indivíduo, cuja expressão é censurada, quanto à totalidade da sociedade, exercer o seu direito à liberdade de expressão e informação" (CIDH, 2000).

É exatamente nesse ponto que envolve a censura prévia da liberdade de expressão que está a problemática deste capítulo. Não seria a imposição da "verdade" uma forma de censurar a liberdade de expressão? Em outras palavras, ao retirar a "informação falsa" do âmbito de proteção conferido à liberdade de expressão não se estaria restringindo o pleno exercício desse direito fundamental por meio de censura indireta?

A resposta para tal questionamento foi construída pela Comissão Interamericana de Direitos Humanos ${ }^{8}$ na Interpretação da Declaração de Princípios sobre a Liberdade de Expressão, cujo raciocínio será demonstrado nos parágrafos que seguem.

Nos termos do Princípio 7 da referida Declaração, quaisquer condicionamentos prévios impostos à expressão de ideias e informações, tais como a veracidade, a oportunidade ou a imparcialidade, são incompatíveis com o direito à liberdade de expressão reconhecido nos instrumentos internacionais (CIDH, 2000).

\footnotetext{
${ }^{8}$ A CIDH, conforme informações obtidas no sítio oficial da OEA (2020), é o principal órgão da Organização dos Estados Americanos (OEA) encarregado da promoção e proteção dos direitos humanos no continente americano. Foi criada pela OEA em 1959 e, juntamente com a Corte Interamericana de Direitos Humanos (CIDH), compõe o Sistema Interamericano de proteção dos direitos humanos (SIDH).
} 
Isso pois, segundo entendimento da Comissão Interamericana de Direitos Humanos (2000), "ao exigir a verdade, a oportunidade ou a imparcialidade na informação, parte-se da premissa de que existe uma verdade única e inquestionável”.

E prossegue afirmando que a exigência de veracidade nas informações pode implicar na sua censura quase automática, por duas razões: 1) primeiro, porque as informações carregadas de juízo de valor, como opiniões e ideias, não podem ser submetidas a comprovação e, portanto, não há como aferir a veracidade ou não da informação; 2) segundo, porque mesmo as informações que se referem a fatos concretos e de provável comprovação factual admitem distintas interpretações, de forma que a exigência de sua veracidade seria um tanto quanto questionável e arbitrária (CIDH, 2000).

Afinal, o que é a verdade senão uma resposta provisória e consensualmente aceita como verdadeira num determinado espaço, em determinada época e por um determinado número de pessoas?

Mas, pressupondo ainda que seja possível encontrar a "verdade sobre todas as coisas, é indubitável que o debate e o intercâmbio de ideias são os métodos indicados para a busca da mesma e o fortalecimento de sistemas democráticos baseados na pluralidade de ideias, opiniões e informações”. E mais: ao impor a necessidade de informar unicamente a verdade, nega-se exatamente a possibilidade de efetuar o debate necessário para alcança-la. A possibilidade de sofrer sanções por informar sobre um tema que, ulteriormente e graças ao debate livre, possa ser considerado como incorreto, conduz à provável autocensura dos informantes para evitar as referidas sanções, e ao consequente prejuízo de todos os cidadãos que não poderão se beneficiar do intercâmbio de ideias (CIDH, 2000).

Depreende-se, portanto, que ao impor a necessidade de informar apenas e tão somente a verdade, impede-se, consequentemente, a realização do debate necessário para alcança-la. A imposição de sanções às informações falsas, errôneas ou incorretas conduz à autocensura dos informantes para evitar as penalidades. Significa que as pessoas muito provavelmente deixarão de se 
manifestar por medo da punição. Sem conseguir determinar com certeza se a informação é falsa ou verdadeira, certa ou errada, até porque a verdade é um conceito extremamente relativo e aberto, os indivíduos e meios de comunicação preferirão se abster a sofrer possíveis sanções.

Consoante Marcio Schusterschitz da Silva Araujo (2017, p. 3435), "o controle da expressão a partir da verdade, apresenta limites consideráveis", ao passo que impõe uma certa contradição com o próprio fundamento da liberdade de expressão, que é o debate. Se a liberdade de expressão tem como principal razão de ser o esclarecimento da sociedade e dos indivíduos, como instrumento para se atingir a verdade, "seria inverter a equação impedir a expressão, de imediato, por ela não ser verdadeira”. Até porque, segundo o autor:

Se a verdade é um caminho que se quer chegar a partir do debate e da expressão, seria infundado exigir a verdade de imediato de toda expressão. Existe um limite na adoção da verdade como critério legitimador do discurso. O reconhecimento do que seja verdadeiro é muitas vezes difícil, e determinar à pessoa a confirmação prévia sobre a verdade do que diz é negar a dinâmica da expressão no meio social. Em grande medida, o problema da verdade se transforma em problema de comprovação ou da fonte. [...]. Se um dos principais fundamentos para a liberdade de expressão é a descoberta da verdade, a expressão antecede a verdade e não a sucede (grifo nosso).

Como ressalta Laurentiis e Thomazini (2020, p. 28), é necessária e importante a proteção até mesmo dos discursos falsos, sem os quais não seria necessário sequer garantir a liberdade de expressão, posto que se todos soubessem o que é certo e verdadeiro, ninguém precisaria dizer absolutamente nada.

Assim sendo, não resta dúvidas de que a imposição da verdade leva à censura prévia da informação, restringe o exercício livre do direito à manifestação de pensamentos, ideias, opiniões e informações, podendo culminar, ainda, no completo esvaziamento do núcleo essencial do direito à liberdade de expressão. 
Por tais razões, a Comissão Interamericana de Direitos Humanos defende que a interpretação correta das normas internacionais e, especialmente do artigo 13 do Pacto de San Jose da Costa Rica, revela que o direito à informação abarca todas as informações, até mesmo aquelas consideradas errôneas, inoportunas ou incompletas.

Por fim, a CIDH (2000) conclui asseverando que a doutrina da informação verdadeira representa um retrocesso para o direito à liberdade de expressão e informação, uma vez que restringe o livre fluxo de informação à sua qualificação prévia como "veraz" ou “errônea”, o que representa uma contradição frontal com a concepção outorgada a este direito dentro do Sistema Interamericano.

A esse respeito também já se manifestou a Corte Interamericana, na opinião consultiva $\mathrm{OC}-5 / 85$, parágrafo 33 , advertindo que "não seria lícito invocar o direito da sociedade a estar informada de forma veraz para justificar um regime de censura prévia supostamente destinado a eliminar as informações que fossem falsas a critério do censor”.

Depreende-se, da interpretação dada pela Corte e Comissão Interamericanas de Direitos Humanos à liberdade de expressão, bem como do entendimento firmado no Marco Jurídico Interamericano sobre o direito à liberdade de expressão (2014, p. 09-21), que a desinformação, quando não configurar discurso não protegido pela liberdade de expressão (propaganda de guerra e a apologia ao ódio que constitua incitação à violência; incitação direta e pública ao genocídio; ou pornografia infantil), nem se enquadrar nas restrições à liberdade de expressão (crimes contra a honra, contra a segurança nacional, entres outros previstos no ordenamento jurídico brasileiro), estará protegida pelo manto da liberdade de expressão. E nesse caso, a caracterização da desinformação como ato ilícito não poderia sequer ser cogitada.

Até porque, tal restrição à liberdade de expressão, assim como a imposição de multa a quem divulga uma informação fraudulenta e a responsabilização objetiva dos provedores pelo conteúdo publicado 
por terceiros, não cumpre as condições básicas de admissibilidade estabelecidas pelo test tripartite, como se demonstrará no capítulo seguinte.

Ressalta-se, por fim, que tal restrição torna-se ainda mais problemática no que concerne à liberdade de expressão na internet. Isso, porque o direito à liberdade de expressão encontra na Internet um forte aliado, representando um amplo espaço para manifestação de ideias, de opiniões e acesso a informações" (SILVA; BOLZAN; CIGANA, 2019, p. 234). A internet é um instrumento essencial à da liberdade de expressão, uma vez que democratizou, ampliou e fortaleceu seu exercício.

Por tal razão, a Declaração Conjunta sobre Liberdade de Expressão e Internet de 2011, em seus princípios gerais, estabeleceu que, para uma restrição à liberdade de expressão online ser admissível, ela também deve cumprir as condições do test tripartite. Quanto à análise da proporcionalidade, destaca, ainda, que se deve ponderar o impacto que ela poderia ter na "capacidade da internet para garantir e promover a liberdade de expressão em relação aos benefícios que a restrição geraria para a proteção de outros interesses” (CIDH, 2011).

\section{OS MECANISMOS DE COMBATE À DESINFORMAÇÃO À LUZ DO TEST TRIPARTITE}

O fenômeno da desinformação gerou uma preocupação a nível global, mais ainda não há um consenso sobre o que deve ser feito para o enfrentamento do problema. A ânsia por uma solução ensejou, nos últimos anos, a adoção, por diversos países, a exemplo da Alemanha, Peru, Egito, Malásia e Tailândia, de leis que regulamentam a liberdade de expressão na internet, ora por meio da responsabilização civil (imposição de multas) ou penal (criminalização) da conduta de publicar, divulgar ou compartilhar notícias falsas, ora mediante a 
responsabilização dos provedores de aplicação (plataformas de redes sociais) pelos conteúdos publicados por terceiros.

Nesta última hipótese, dois modelos se apresentam: o primeiro deles, que vige atualmente no Brasil pelo Marco Civil da Internet (e cuja constitucionalidade está sendo discutida - RG n ${ }^{\circ} 987$ e $553 \mathrm{STF}$ ), reserva ao judiciário a prerrogativa de determinar a exclusão dos conteúdos ilícitos (salvo a exceção prevista no artigo 21, do MCI), de forma que a responsabilização civil das plataformas depende do descumprimento da ordem judicial; o segundo modelo, por sua vez, baseia-se numa espécie de autorregulação, de modo que, aos provedores, caberia a atribuição de verificar a veracidade das informações postadas, tirando-as do ar ou mesmo tarjando-as como "falsas", numa espécie de censura por delegação (FONSECA; RODRIGUES, 2019, p. 18).

Nesta autorregulação, também podem ser incluídas alterações na própria arquitetura do provedor de aplicação mediante a limitação do tamanho dos grupos e do número de compartilhamentos no WhatsApp, por exemplo, a exigência de apresentação de documentos de identidade pelo usuário, suspensão de usuários que tiverem suas contas telefônicas desabilitadas pelas operadoras de telefonia, armazenamento de registros de mensagens por certo lapso temporal, dentre outros mecanismos que podem representar mais ameaças à privacidade, proteção de dados e liberdade de expressão do que avanços no combate às fake news.

No Brasil, embora ainda não haja nenhuma lei federal vigente sobre fake news (talvez por pouco tempo), desde 2015 foram mais de 20 projetos de lei propostos com o intuito de regulamentar a matéria no ordenamento jurídico pátrio. $\mathrm{E}$ em decorrência da onda de desinformação que acompanhou a Pandemia de COVID-19, a preocupação com o combate às fake news se intensificou ainda mais. Recentes legislações de alguns Estados brasileiros, como Acre, Ceará, Paraíba, Roraima e Rio Grande do Norte, passaram a fixar multas que variam de mil a cinquenta mil reais, a depender do Estado, para quem dolosamente divulgar, por meio eletrônico ou similar, informações 
falsas sobre pandemias, epidemias e endemias. Dispõem, ainda, que ocorrendo inadimplência no pagamento da multa, o cidadão ficará proibido de prestar concurso público, bem como de assumir qualquer cargo público.

O debate reaqueceu também no Senado, especialmente com a propositura, pelo Senador Alessandro Vieira, do projeto de lei $\mathrm{n}^{\circ} 2630$ de 2020, que visa instituir a Lei Brasileira de Liberdade, Responsabilidade e Transparência na Internet, e cuja tramitação vem ensejando severas críticas. O texto base do PL foi aprovado pelo Senado Federal em 30 de junho de 2020, e engloba várias das medidas que atribuem responsabilidade aos provedores no combate à desinformação acima mencionadas, como armazenamento de registros de mensagens, limitação de compartilhamento de mensagens, limitação de usuários por grupo, o poder de verificar e excluir postagens sem necessidade de autorização judicial, imposição de advertência, multas às plataformas, etc.

A problemática de se estabelecer uma regulação sobre fake news começa com a dificuldade de atingir uma compreensão unívoca quanto à conceituação e conteúdo da desinformação. Em outras palavras, o primeiro grande problema está essencialmente na dificuldade de se determinar se a notícia é ou não falsa. Ainda mais difícil é garantir que esse "julgamento" seja isento das convicções pessoais do julgador.

Como enfatizou Flúvio Garcia, no Seminário Internacional sobre Fake News e Eleições (2019, p. 82-83), é claro que, nos extremos, é fácil identificar uma notícia falsa, mas "existe uma zona cinzenta que sequer temos a possibilidade de dizer se se trata efetivamente de fake news ou não”. E segue com os seguintes questionamentos: ora, como criminalizar uma conduta que nem se sabe ao certo qual é? Como iniciar uma investigação no âmbito da polícia judiciária para coibir esse tipo de ação se não há sequer alguma objetividade nesse contexto? 
A este respeito, a Declaração Conjunta sobre Liberdade de Expressão e Notícias falsas, Desinformação e Propaganda de 2017 adverte que "as proibições gerais à disseminação de informações com base em conceitos imprecisos e ambíguos, incluindo "notícias falsas ou "informações não objetivas", são incompatíveis com os padrões internacionais sobre restrições à liberdade de expressão, e devem ser revogadas" (CIDH, 2017).

De forma semelhante, a Declaração Conjunta sobre Liberdade de Expressão e Eleições na Era Digita de 2020 recomenda aos Estados que não adotem leis geais ou ambíguas sobre desinformação, com a utilização de termos como "falsidades ou "informações não objetivas" (CIDH, 2020).

Ora, se o próprio termo objeto da regulação (desinformação) não possui conceituação e definição unívocas, como seria possível estabelecer uma regulação clara e precisa, capaz de cumprir a primeira condição básica do test tripartite? A imprecisão técnica acerca do conteúdo e definição da desinformação, e também da "verdade" (posto que até os fatos admitem distintas interpretações) não permite afirmar que tal restrição seja legítima frente ao Sistema Interamericano de Direitos Humanos. Ainda mais se levada em consideração a dificuldade de se identificar, na prática, qual notícia se caracteriza como desinformação.

Vislumbrando justamente essa imprecisão que é intrínseca ao fenômeno da desinformação, o Guia para garantir a liberdade de expressão frente à desinformação deliberada em contextos eleitorais (2019, p. 23) elaborado pela Relatoria Especial para a Liberdade de Expressão da $\mathrm{CIDH}$, recomenda que os Estados não estabeleçam novos tipos criminais para sancionar a desinformação:

Este guia recomenda que os estados da região, em conformidade com os padrões do sistema interamericano de direitos humanos, não devem estabelecer novos tipos criminais para sancionar a disseminação de desinformação ou de notícias falsas. Introduzir tipos criminosos que, pela natureza do fenômeno, seriam vagos ou ambíguos, poderia trazer de volta [...] uma ferramenta com forte efeito inibitório sobre a disseminação de ideias, 
críticas e informações, devido ao medo de sofrer um processo criminal [...] ${ }^{9}$ (grifo nosso).

Quanto à ineficácia de tais medidas no combate às fake news, Cristina Tardáguila adverte que não há nenhum dado capaz de comprovar que a elaboração de leis acarrete na diminuição de notícias falsas (BENEVIDES, 2020).

Na mesma linha é tecida a crítica de Lenio Luiz Streck (2020) aos projetos de lei que visam regulamentar a liberdade de expressão na internet: eles não se baseiam em dados ou elementos científicos, mas em resultados imaginários, em "jogos morais", sobre os quais não têm nenhuma certeza, ou melhor, sobre os quais não podem dar nenhuma convicção de que melhorará o sistema.

A descrença na tipificação penal e na fixação de multa como forma de solucionar o problema se deve, inicialmente, ao volume de notícias falsas que circulam nas redes todos os dias, de forma que seria pouco provável, ou mesmo impossível investigar e punir todos os casos de desinformação. O que resultaria em mais um diploma legal meramente decorativo, sem apresentar, contudo, relevante eficácia prática.

No ímpeto de oferecer uma resposta imediata ao que aparenta ser hoje o grande mal da intitulada "sociedade da informação", os parlamentares buscam, numa "correria" insensata, aprovar projetos de leis falhos, desproporcionais e perigosos acerca da regulação da liberdade de expressão na internet. $\mathrm{E}$, assim, tende-se à irracional perpetuação do direito penal simbólico, que muito diz, mas nada faz.

Nesse sentido, o Professor Paulo Rená enfatiza, ainda, que acreditar que a criação de um tipo penal poderá impedir a existência de notícias falsas é uma infeliz "miopia”. Segundo ele, a proposta penal

\footnotetext{
9 Tradução do autor. No original: "Esta guía recomienda que los Estados de la región, en línea con los estándares del sistema interamericano de derechos humanos, no deberían establecer nuevos tipos penales para sancionar la difusión de desinformación o de noticias falsas. Introducir tipos penales, que por la naturaleza del fenómeno serían vagos o ambiguos, podría retrotraer a la región a uma lógica de criminalizar expresiones sobre funcionarios o personas involucradas en asuntos de interés público y establecer una herramienta con un fuerte efecto inhibitorio de la difusión de ideas, críticas e información por miedo a sufrir un proceso penal [...]”.
} 
é inadequada, especialmente, porque diante de uma quantidade imensurável de posts, não é possível prender ou processar todo mundo que compartilhar algo. Consequentemente, apenas alguns casos serão levados à Justiça que, por sua vez, corre o risco de tornar-se ainda mais seletiva, empunhando sua espada apenas a determinado grupo, classe social ou candidato, por exemplo (GRIGORI, 2018).

Ademais, conforme asseverou Ricardo Gutiérrez, no Seminário Internacional sobre Fake News e Eleições (2019, p. 30), a referida criminalização seria disparatadamente contraprodutiva, posto que uma vez banido o conteúdo falso, ele poderia ser imediatamente republicado em outro servidor. Afinal, a produção e divulgação de notícias falsas, ainda mais quando promovidas por bots ou ciborgues, é imensa, incessante e incontrolável. Como bem destaca Claire Wardle, "desinformação é um fenômeno social que pode ser comparado à poluição. E combatê-lo é como varrer as ruas" (PIMENTA, 2017). Não importa o quanto se tente limpar, a rua sempre estará repleta de folhas e sujeira.

A este respeito, segundo Reynaldo S. da Fonseca e Matheus V. A. Rodrigues (2019, p. 17), “o Judiciário, em sua função típica, parece ser uma ferramenta pouco eficiente para se combater a fabricação e a disseminação de notícias fraudulentas". E a razão para tal ineficiência é evidente: o controle judicial apresenta uma limitação natural diante da hipervelocidade da difusão das fake news que o impede, ainda que por medidas de urgência, de combater tais notícias antes de sua "viralização" na rede.

Por fim, adverte Zachery Lampell que não está claro o quanto essas leis sobre fake news conseguem limitar a disseminação de desinformação sobre a covid-19, sendo provável que, em vez de impedir a propagação de notícias falsas, elas acabem sufocando a mídia independente, intimidando o debate público e enfraquecendo a democracia (BENEVIDES, 2020).

Vislumbra-se, portanto, que a criminalização da desinformação, seja relacionada à saúde pública ou não, tende a ser ineficaz, contraproducente e apto a fazer surgir uma justiça seletiva e 
tendenciosa. Não aparenta ser, portanto, idônea a atingir o fim a que se destina. Descumpre, desse modo, mais uma condição básica do test tripartite, o que a caracteriza como restrição ilegítima e inadmissível à liberdade de expressão.

O perigo fulcral da responsabilização civil e penal dos cidadãos está na censura. A imposição de sanções a quem divulgar uma informação falsa tende a gerar a imediata autocensura do informante, que se absterá de divulgar a informação para evitar uma futura penalidade, como já demonstrado no capítulo anterior. Haverá, assim, um estado de censura prévia e de restrição indireta à liberdade de expressão, numa afronta direta ao texto constitucional e convencional (da convenção americana de direitos humanos). A autocensura implicará na restrição da liberdade de imprensa e de informação, tanto em seu aspecto individual (o direito de informar), quanto coletivo (o direito das outras pessoas de serem informadas).

A longo prazo (se comparado à autocensura), a previsão de multas ou penas privativas de liberdade para quem divulgar uma notícia fraudulenta terá como consequência o controle posterior das informações que forem publicadas por um órgão censor (seja ele um juiz ou uma corte especializada), que, a seu critério, dirá o que é mentira e o que é verdade, o que deve ser mantido na rede ou o que deve ser calado, o que é fato e o que não é. Com a censura sempre vem um censor que, sendo dono da verdade, a impõe sobre todos.

O espaço para arbitrariedades é imenso, ainda mais se considerada a imprecisão técnica acerca do conteúdo e definição da desinformação, e também da "verdade”. Surge, então, o seguinte questionamento: há proporcionalidade em tais mecanismos de combate à desinformação, isto é, os benefícios gerados por tais restrições serão maiores do que os prejuízos gerados à livre manifestação de ideias, opiniões e informações? Tudo indica que a tentativa de combate à desinformação por meio da responsabilização civil e penal daqueles que divulgam notícias falsas, além de incapaz de atingir sua finalidade, acabará suprimindo o direito de todos os 
cidadãos de transmitir e receber informações, tornando-se um obstáculo a própria liberdade de expressão.

Tais restrições são, portanto, duplamente ilegítimas, uma vez que implicam necessariamente em censura prévia e não cumprem o requisito da proporcionalidade, em expressa violação ao entendimento fixado pela Comissão Interamericana de Direitos Humanos no Marco Jurídico Interamericano sobre o Direito à Liberdade de Expressão.

Ainda mais perigosa se revela a atribuição, aos provedores (intermediários), da responsabilidade por controlar e filtrar os conteúdos postados pelos usuários. Pois ao assumir a função de controlador do conteúdo, o provedor de aplicação estaria, no fundo, assumindo a função de controlador da liberdade de expressão do usuário, e "o papel ativo do provedor de aplicação, no interesse de evitar uma eventual responsabilidade civil, fundaria uma privatização da censura" (ARAUJO, 2017, p. 31-32).

Acerca do tema, como já mencionado, a Declaração Conjunta sobre Liberdade de Expressão e Notícias falsas, Desinformação e Propaganda de 2017, expressamente repudia a privatização das medidas de controle que transferem aos intermediários a realização de ações que restringem o conteúdo (CIDH, 2017).

No entendimento da CIDH, expresso na Declaração Conjunta sobre Liberdade de Expressão e Internet de 2011, os provedores só poderão ser responsabilizados por conteúdos gerados por terceiros quando intervirem diretamente em tais conteúdos ou descumprirem ordem judicial que exija a eliminação do conteúdo quando estiver em condições de fazê-lo, dado o princípio da mera transmissão (CIDH, 2011).

Tal compreensão foi, inclusive, ratificada pela CIDH, no Guia para garantir a liberdade de expressão frente à desinformação deliberada em contextos eleitorais (2019, p. 34), que recomenda ao Poder Legislativo dos Estados Membros que "evite estabelecer marcos regulatórios que responsabilizem os intermediários por conteúdos produzidos por terceiros", posto que eles tendem a excluir 
ostensivamente os conteúdos para evitar serem sancionados, afetando drasticamente a liberdade de expressão.

Conforme ressalta Marcel Leonardi (2012), “responsabilizar objetivamente qualquer provedor de serviços de Internet pelos atos de seus usuários traria, como consequência imediata, o estabelecimento de políticas agressivas de censura da conduta de tais usuários”. Configura, pois, limitação injusta e desproporcional à liberdade de expressão, não admitida pela Organização dos Estados Americanos.

A Declaração Conjunta sobre Liberdade de Expressão e Eleições na Era Digital de 2020 - ante a preocupação com o fato de muitos Estados estarem promulgando leis que, embora formalmente justificadas no interesse de resolver a desinformação, "limitam indevidamente a liberdade de expressão, ampliam o controle estatal sobre a mídia, restringem a liberdade da Internet e/ou ampliam o poder de vários atores para coletar dados pessoais" -, reafirma, mais uma vez, a necessidade da alfabetização midiática e da adoção de outras medidas "positivas para resolver o problema da desinformação on-line, como promover organismos independentes para verificação de informações e campanhas de educação pública”, evitando a criminalização da desinformação (CIDH, 2020).

A Declaração Conjunta sobre Liberdade de Expressão e Internet de 2011 e a Declaração Conjunta sobre Liberdade de Expressão e Notícias falsas, Desinformação e Propaganda de 2017 também já haviam advertido os Estados sobre a necessidade de evitar restrições especiais ao conteúdo dos materiais que são difundidos por meio da internet, priorizando as abordagens alternativas no combate a conteúdos ilícitos, como medidas "educativas e de conscientização destinadas a promover a capacidade de todas as pessoas de fazer um uso autônomo, independente e responsável da internet” (CIDH, 2011). Isto é, promover a alfabetização digital, "incluindo esses tópicos nos currículos acadêmicos regulares e envolvendo a sociedade civil e outras partes interessadas para aumentar a conscientização sobre essas questões” (CIDH, 2017). 
Os indivíduos devem ser tratados como seres autônomos e capazes de analisar as informações e tirar suas próprias conclusões, sem que o Estado tenha que filtrar todo conteúdo que chega ao conhecimento de seus cidadãos. Não é papel do Estado controlar a informação e cuidar de seu povo como se crianças frágeis e ingênuas fossem.

Nesse sentido, também argumenta Marcio Schusterschitz da Silva Araujo (2017, p. 32-33) ao afirmar que "não é, em regra, competência legítima do Estado em proteger as pessoas contra falsas ideias. São as pessoas, em sua autonomia, o árbitro de suas próprias crenças e agentes do próprio conhecimento".

Como se observa, a Comissão Interamericana de Direitos Humanos vem se mantendo firme acerca da necessidade de se evitar a responsabilização dos provedores (salvo quando intervirem na formação do conteúdo ou descumprirem ordem judicial), e a criminalização da desinformação, que deve ser combatida com medidas de alfabetização digital, conscientização e mecanismos de checagem de fatos (os fact-checking).

É preciso, pois, não suprimir ou restringir a liberdade de expressão, mas disponibilizar meios que capacitem o próprio indivíduo a compreender e filtrar a informação que recebe. É preciso promover a alfabetização digital. Este é o entendimento da Comissão Interamericana de Direitos Humanos - reforçada, novamente, no Guia para garantir a liberdade de expressão frente à desinformação deliberada nos contextos eleitorais (2019, p. 39).

A título de exemplo, Ricardo Gutiérrez, em sua fala no Seminário Internacional sobre Fake News e Eleições (2019, p. 27-28), defendeu que:

A ideia global aqui é, em vez de focar na supressão ou na censura, é, por outro lado - o que faz muito mais sentido - criar a imunidade à fake news enquanto sociedade [...] através da promoção da alfabetização midiática. Precisamos fornecer instrumentos aos nossos cidadãos para que eles possam fazer a diferença entre uma fonte de informação confiável e uma não confiável. 
Neste mesmo Seminário (2019, p. 64), Maurício Moura ressaltou a relevância da alfabetização midiática ao afirmar que não acredita em medida mais efetiva do que a educação no combate às fake news, até porque a tecnologia e a complexidade da inteligência artificial se desenvolvem num ritmo tão acelerado que se torna cada vez mais difícil o combate às fake news por outros mecanismos que não sejam a imunização da sociedade por meio da educação. Segundo Maurício, o combate às fake news está na sala de aula. Na Finlândia e na Suécia as aulas de checagem de informação já são uma realidade que tende a se espalhar para os demais países do globo.

A educação, não por acaso, sempre foi a resposta para a maioria esmagadora dos problemas sociais. Há de se considerar, entretanto, que a alfabetização midiática é um mecanismo apto a proporcionar uma solução a longo prazo, visto que sua implementação surtirá efeitos somente após alguns anos. E, nesse aspecto, não satisfaz a necessidade imediata de combate à desinformação.

Visando, então, promover uma atuação em duas frentes - de criar imunidade social por meio da educação, bem como permitir o combate imediato da desinformação - deve-se ressaltar a importância de aliar a alfabetização midiática à promoção de medidas de conscientização e à atuação de plataformas independentes de checagem de fatos.

Como advertem Vinícius B. Fortes e Wellington A. Baldissera (2019, p. 397), o melhor caminho é combater a desinformação com informação, ou seja, indicar, no próprio local onde a falsidade foi divulgada, a informação verdadeira ou onde encontrá-la. Além disso, segundo os autores, uma maior divulgação na televisão e rádio sobre a existência das notícias falsas e importância de verificar a informação antes de publicá-la também poderia apresentar resultados eficientes no combate à desinformação.

Nesse sentido, merece destaque a atuação do Superior Tribunal Eleitoral (TSE) que vem promovendo, em horário nobre da televisão, propagandas para informar sobre a existência das fake news e a 
importância de checar as informações antes de compartilhá-las. No sítio do TSE também é possível encontrar esclarecimentos sobre informações falsas na seção denominada "Fato ou Boato". O Ministério da Saúde também conta com uma seção sobre fake news em seu sítio oficial, além de disponibilizar um número de WhatsApp "para receber informações virais que serão apuradas pelas áreas técnicas e respondidas oficialmente se são verdade ou mentira".

Das plataformas independes de fact-checking citam-se as agências Lupa, O Truco, Aos Fatos e Estadão Verifica, todas certificadas pelo IFCN (International Fact-checking Network) e que, portanto, seguem os critérios de transparência das fontes, apartidarismo e imparcialidade, transparência da metodologia utilizada e da forma de organização e financiamento da agência, bem como uma política de correções aberta e franca.

O serviço de checagem de fatos prestado pela sociedade civil organizada, consoante Reynaldo S. da Fonseca e Matheus V. A. Rodrigues (2019, p. 104), revela-se essencial no combate às fake news, "sobretudo diante da velocidade de transmissão de informações introduzidas pelo advento das mídias digitais".

Tais iniciativas de conscientização e checagem de fatos, aliadas à alfabetização midiática, devem, portanto, de acordo com recomendações exaradas pela Comissão Interamericana de Direitos Humanos, ser fortalecidas e ampliadas, uma vez que compreendem ferramentas notadamente promissoras no combate à desinformação, não apenas em razão de seu caráter célere e acessível, mas principalmente porque não trazem consigo o perigo de esvaziamento do direito à liberdade de expressar livremente pensamentos, ideias, opiniões e informações. 


\section{CONSIDERAÇÕES FINAIS}

O fenômeno da desinformação, especialmente na Era Digital e Pós-fato, representa um problema real da sociedade em rede com consequências muitas vezes desastrosas e que, portanto, exige uma resposta. Diversos são os mecanismos de combate às fake news, mas nem todos se mostram realmente adequados a sanar um mal (desinformação) sem suprimir ou restringir um direito (liberdade de expressão).

Dessa forma, analisou-se alguns dos mecanismos de combate à desinformação à luz das recomendações da Comissão Interamericana de Direitos Humanos e do test tripartite desenvolvido pela Jurisprudência Interamericana com o objetivo de avaliar sua legitimidade e eventual potencial supressivo do direito humano e fundamental à liberdade de expressão.

Verificou-se, primeiramente, que a informação falsa, à luz do Sistema Interamericano de Direitos Humanos, está incluída no âmbito de proteção jurídica conferido à liberdade de expressão, uma vez que imposição de sanções às informações falsas, errôneas ou incorretas conduz à autocensura dos informantes para evitar as penalidades, restringindo o exercício livre do direito à manifestação de pensamentos, ideias, opiniões e informações. Isto é, a exigência de veracidade na informação tende a se degenerar em restrições indevidas à liberdade de expressão.

Assim sendo, a desinformação, quando não configurar discurso não protegido pela liberdade de expressão (propaganda de guerra e a apologia ao ódio que constitua incitação à violência; incitação direta $\mathrm{e}$ pública ao genocídio; ou pornografia infantil), nem se enquadrar nas restrições à liberdade de expressão (crimes contra a honra, contra a segurança nacional, entres outros previstos no ordenamento jurídico brasileiro), estará protegida pelo manto da liberdade de expressão. E 
nesse caso, a caracterização da desinformação como ato ilícito não poderia sequer ser cogitada.

Concluiu-se, outrossim, que a responsabilização civil ou penal de quem divulga informações fraudulentas, assim como a responsabilização objetiva das plataformas pelos conteúdos publicados por terceiros, ante a imprecisão que permeia a definição e conteúdo da desinformação, intrínseca à própria natureza do fenômeno, constituem restrições extremamente perigosas à liberdade de expressão e ilegítimas, porquanto não cumprem os requisitos básicos fixados pelo test tripartite, sobretudo o requisito da proporcionalidade, uma vez que os eventuais benefícios que poderiam acarretar na proteção da "verdade" e de outros direitos são ínfimos se comparados aos graves danos que impõem na capacidade da internet para garantir e promover a liberdade de expressão.

Por fim, inferiu-se que o entendimento da Comissão Interamericana de Direitos Humanos e, por conseguinte, a sua recomendação aos Estados Nacionais é no sentido de: 1) evitar tanto a responsabilização civil e penal daqueles que divulgam ou compartilham notícias fraudulentas quanto a responsabilização objetiva dos provedores de aplicação sobre conteúdos divulgados por terceiros; e 2) promover a alfabetização midiática e a adoção de outras medidas positivas no combate à desinformação online, como o incentivo a organismos independentes de verificação de fatos e a adoção de medidas de conscientização da população, posto que representam alternativas muito promissoras no combate à desinformação e não oferecem riscos ao pleno exercício da liberdade de expressão.

Depreende-se, portanto, que a solução para a problemática da desinformação não está na imposição do silêncio, mas na promoção de mais liberdade de expressão. A solução mais razoável, proporcional e segura está na alfabetização midiática, na conscientização da população e nas plataformas de checagem de fatos. Desinformação não se combate com censura. Desinformação se combate com informação. 
Mecanismos De Combate À Desinformação: Uma Análise À Luz Da Comissão...

Data de Submissão: 19/08/2020

Data de Aprovação: 15/03/2021

Processo de Avaliação: double blind peer review

Editor Geral: Jailton Macena de Araújo

Editor de Área: Alana Ramos Araújo

Assistente Editorial: Iasmin Madeiro Cordeiro

\section{REFERÊNCIAS}

ALLCOTT, Hunt; GENTZKOW, Matthew. Social Media and Fake news in the 2016 Election. Journal of Economic Perspectives, v. 31, n. 2, p. 211-236, 2017. Disponível em: https://bit.ly/3fCvRl4. Acesso em: 10 jul. 2020.

ARAUJO, Marcio Schusterschitz da Silva. Liberdade de Expressão. 2017. E-book. Disponível em: https://bit.ly/30KglQ8. Acesso em: 23 jul. 2020.

BARROSO, Luís Roberto. Colisão entre Liberdade de Expressão e Direitos da Personalidade. Critérios de Ponderação. Interpretação Constitucionalmente Adequada do Código Civil e da Lei de Imprensa. Revista de Direito Administrativo, v. 235, p. 1-36, mar, 2004. Disponível em: https://bit.ly/3fABPCY. Acesso em: o6 jul. 2020.

BENEVIDES, Bruno. Número de países com regulação contra fake news dispara durante a pandemia: Especialistas alertam que a medida pode abrir brecha para a supressão da liberdade de expressão e de imprensa. Gauchazh, abr. 2020. Disponível em: https://bit.ly/3gzZchw. Acesso em: 05 jul. 2020.

BENTIVEGNA, Carlos Frederico Barbosa. Liberdade de expressão, honra, imagem e privacidade: Os limites entre o lícito e o ilícito. 1. ed. Barueri: Editora Manole Ltda., 2020. Ebook.

BRAGA, Renê Morais da Costa. A indústria das fake news e o discurso de ódio. Direitos políticos, liberdade de expressão e discurso de ódio. v. 1, p. 203-220. Belo Horizonte: IDDE, 2018. Disponível em: https://bit.ly/2DBCo2n. Acesso em: 15 jul. 2020.

BRASIL. Constituição da República Federativa do Brasil de 1988. Brasília, DF: 
Presidência da República. Disponível em: https://bit.ly/2H18PZJ. Acesso em: 14 set. 2020.

BRASIL. Decreto $n^{\circ} .678$, de 6 de novembro de 1992. Promulga a Convenção Americana sobre Direitos Humanos (Pacto de São José da Costa Rica), de 22 de novembro de 1969. Disponível em: https://bit.ly/2RuwiV6. Acesso em: 14 set. 2020.

BRASIL. Decreto-lei $\mathbf{n}^{\circ} \mathbf{2 . 8 4 8}$, de 7 de dezembro de 1940. Código Penal. Rio de Janeiro: Presidência da República. Disponível em: https://bit.ly/33wuQHe. Acesso em: 14 set. 2020

BRASIL. Lei $\mathbf{n}^{\circ} \mathbf{4 \cdot 7 3 7}$, de 15 de julho de 1965. Institui o Código Eleitoral. Brasília, DF: Presidência da República. Disponível em: https://bit.ly/3hDjvKN. Acesso em: 14 set. 2020.

BRASIL. Lei no 12.965, de 23 de abril de 2014. Estabelece princípios, garantias, direitos e deveres para o uso da Internet no Brasil. Brasília, DF: Presidência da República. Disponível em: https://bit.ly/2ZBPGUK. Acesso em: 14 set. 2020.

BRASIL. Lei no 8.069, de 13 de julho de 1990. Dispõe sobre o estatuto da criança e do adolescente e dá outras providências. Brasília, DF: Presidência da República. Disponível em: https://bit.ly/3hqn86p. Acesso em: 14 set. 2020.

BRASIL. STF. Primeira Turma. Reclamação 22.328 Rio De Janeiro. Relator: Min. Roberto Barroso. Julgamento: 06/03/2018. Disponível em: https://bit.ly/3fAESeD. Acesso em: o8 jul. 2020.

CASTELLS, Manuel. A Sociedade em Rede: do Conhecimento à Política. In: CASTELLS, Manuel; CARDOSO, Gustavo. A Sociedade em Rede: Do Conhecimento à Acção Política. 2005. Conferência promovida pelo Presidente da República, Belém, 2005. Disponível em: https://bit.ly/3morOgX. Acesso em: 14 set. 2020.

CIDH. Declaração Comum sobre a Liberdade de Expressão e Eleições na Era Digital. Adotada em 30 de abril de 2020. Disponível em: https://bit.ly/2W4fdnt. Acesso em: 28 jul. 2020.

CIDH. Declaração conjunta sobre liberdade de expressão e "notícias falsas", desinformação e propaganda. Adotada em Viena, em 3 de março de 2017. Disponível em: https://bit.ly/2Cj97IX. Acesso em: 29 jul. 2020.

CIDH. Declaração Conjunta sobre Liberdade de Expressão e Internet. Adotada em $1^{\circ}$ de junho de 2011. Disponível em: https://bit.ly/2ZbRpjI. Acesso em: 28 jul. 2020. 
Mecanismos De Combate À Desinformação: Uma Análise À Luz Da Comissão...

CIDH. Declaração de Princípios sobre Liberdade de

Expressão. Adotada em outubro de 2000. Disponível em: https://bit.ly/3ggrufU. Acesso em: 28 jul. 2020.

CIDH. Guía para garantizar la libertad de expresión frente a la desinformación deliberada en contextos electorales. Elaborada por la Relatoría Especial para la Libertad de Expresión de la Comisión Interamericana de Derechos Humanos. Adotado em outubro de 2019. Disponível em: https://bit.ly/3fsXLQA. Acesso em: 05 jul. 2020.

\section{CIDH. Marco jurídico interamericano sobre o direito à} liberdade de expressão. 2014. Aprovado em 30 de dezembro de 2009. Versão em português, maio de 2014. ISBN 978-0-8270-54578. Disponível em: https://bit.ly/3hynjwz. Acesso em: 25 jul. 2020.

COMPROVA. Home. Sítio oficial do Projeto Comprova.

Disponível em: https://bit.ly/3fzFd14. Acesso em: 29 jul. 2020.

CORTE I.D.H. Opinión Consultiva - OC-5/85 del 13 de

Noviembre de 1985. Disponível em: https://bit.ly/2XyCTRS. Acesso em: 05 jul. 2020.

CORTE I.D.H. Sentença de 20 de novembro de 2009. Caso Usón Ramírez Vs Venezuela. Disponível em: https://bit.ly/2W34jyq. Acesso em: 30 jul. 2020.

DUCH, Jaume, El Foro sobre Fake News: cómo combatir las noticias falsas en Europa. Apertura realizada por Jaume Duch, Director General de Comunicación y Portavoz del Parlamento Europeo. Disponível em: https://bit.ly/3ikwaD7. Acesso em: 25 jul. 2020.

FERNANDES, André de Godoy. Meios de comunicação social no Brasil: promoção do pluralismo, direito concorrencial e regulação. 2009. 316 p. Tese (Doutorado em Direito) - Faculdade de Direito da Universidade de São Paulo, São Paulo, 2009. Disponível em: https://bit.ly/33vr9TW. Acesso em: o8 jul. 2020.

FONSECA, Reynaldo Soares da; RODRIGUES, Matheus Vinícius Aguiar. Para além do Judiciário: O Controle Judicial da Fake News no Processo Democrático Eleitoral. Revista Direito.UnB, v. 03, n. 1, p. 89-112, 2019. Disponível em: https://bit.ly/31JLjXY. Acesso em: 30 jul. 2020.

FORTES, Vinícius Borges; BALDISSERA. Wellington Antonio. Regulação das Fake News e Liberdade de Expressão: Uma análise a partir da Reclamação 22.328 do Supremo Tribunal Federal. Revista Direitos Sociais e Políticas Públicas - Unifafibe, v. 7, n. 3, p. 
374-401, 2019. Disponível em: https://bit.ly/33pxPkM. Acesso em: 05 jul. 2020.

GENESINI, Silvio. A pós-verdade é uma notícia falsa. Revista USP, n. 116, p. 45-58, 2018. Disponível em: https://bit.ly/2DZSELb. Acesso em: 07 jul. 2020.

GRIGORI, Pedro. 20 projetos de lei no Congresso pretendem criminalizar fake news. Publica, Agência de Jornalismo Investigativo, maio 2018. Disponível em: https://bit.ly/3l1v4hG. Acesso em: 12 jul. 2020.

HASAN, Haya R.; SALAH; Khaled. Combating Deepfake Videos Using Blockchain and Smart Contracts. Revista IEEE Acess, v. 7, p. 41596-41606, 2019. Disponível em: https://bit.ly/2ZQWiP4. Acesso em: 5 set. 2020.

HLEG. A multi-dimensional approach to disinformation. Report of the independente High level Group on fake news and online disinformation. 2018. Disponível em: https://bit.ly/2PGytnv. Acesso em: 15 jul. 2020.

LAURENTIIS, Lucas Catib de. THOMAZINI, Fernanda Alonso. Liberdade de Expressão: teorias, fundamentos e análise de casos. Revista Direito e Praxis, Rio de Janeiro, v. 11, n. 4, p.2260-2301, 2020. Disponível em: https://bit.ly/3qzHhwf. Acesso em: 02 fev. 2021.

LEONARDI, Marcel. Tutela e privacidade na internet. 1. ed. São Paulo: Saraiva, 2012.

LEVINSON, Paul. Fake news in real context. Connected Editions, 2017. E-book.

LOPES, Plínio. A Droga da Desinformação. Revista Piauí, jun. 2020. Disponível em: https://bit.ly/3ifpZ2U. Acesso em: 17 jul. 2020.

MENDEL, Toby; CASTILLEJO, Ángel García; GÓMEZ, Gustavo. Concentración de médios y libertad de expresión: Normas globales y consecuencias para las Américas. Cuadernos de Discusión de Comunicación e Información $\mathrm{n}^{\circ} 7$. Traducción del inglés: Victoria De Negri. UNESCO, 2017. Disponível em: https://bit.ly/3kvggHN. Acesso em: 28 jul. 2020.

MENDEL, Toby; SALOMON, Eve. Liberdade de Expressão e Regulação da Radiodifusão. Série Debates Comunicação e Informação ${ }^{\circ}$ 8. Tradução: Antonio Ribeiro. Brasília: UNESCO, 2011. Disponível em: https://bit.ly/31iSAok. Acesso em: 28 jun. 2020. 
MINISTÉRIO DA SAÚDE. Sítio oficial. Fake News. Disponível em: https://bit.ly/3auDaMj. Acesso em: 02 fev. 2021.

MORALES, Ulrich Richter. El Ciudadano Digital: Fake news y posverdad en la era de internet. México: Editorial Océano, 2018. Ebook. Disponível em: https://bit.ly/2PGCvw9. Acesso em: 11 jul. 2020.

OEA. O que é a CIDH. Sítio Oficial da OEA. 2020. Disponível em: https://bit.ly/3kjszqA. Acesso em: 01 ago. 2020.

OXFORD, Dictionaries. Post-Truth. 2019. Disponível em: https://bit.ly/2Dzw5w5. Acesso em: 10 jul. 2020.

PIMENTA, Angela. Claire Wardle: combater a desinformação é como varrer as ruas. Observatório da Imprensa. Ed. 966, nov. 2017. Disponível em: https://bit.ly/2Fu4e1x. Acesso em: 29 jun. 2020.

PINTO, Pedro Duarte. Liberdade de expressão, mercado, intervenção governamental e o pluralismo nos meios de comunicação. Revista de Direito Público da Economia: RDPE, v. 13, n. 51, p. 159- 186. Belo Horizonte, 2015.

RAIS, Diogo. A melhor tradução para fake news não é notícia falsa, é notícia fraudulenta. [Entrevista cedida a] Pedro Canário. Consultor Jurídico, São Paulo, 2018. Disponível em: https://bit.ly/3ovuSPt. Acesso em: 15 jul. 2020.

RAIS, Diogo; SALES, Stela Rocha. Fake News, Deepfakes e Eleições. In: RAIS, Diogo (org.). Fake News: a conexão entre desinformação e o direito. 2. ed. São Paulo: Thomson Reuters Brasil, 2020.

SEMINÁRIO INTERNACIONAL FAKE NEWS E ELEIÇÕES, 2019, Brasília, DF. Anais [...]. Brasília: Tribunal Superior Eleitoral, 2019. 152 p. Disponível em: https://bit.ly/3ahdXmT. Acesso em: o6 jul. 2020,

SILVA, Carlos Eduardo Lins da. Morte e vida da imprensa. Edição brasileira da Columbia Journalism Review: Da pós-verdade ao risco da pós-imprensa. Observatório da Imprensa.

Ed. 1012. 2018. Disponível em: https://bit.ly/3lovHYM. Acesso em: 26 jun. 2020.

SILVA, Rosane Leal da; BOLZAN, Bárbara Eleonora Taschetto; CIGANA, Paula Fabíola. A Liberdade de Expressão e seus limites na Internet: Uma análise a partir da perspectiva da Organização Dos Estados Americanos. Revista Direitos e Garantias

Fundamentais, Vitória, v. 20, n. 1, p. 219-250, 2019. Disponível em: https://bit.ly/3ad4U6n. Acesso em: 27 jul. 2020. 
STRECK, Lenio Luiz. Liberdade de expressão na internet: não joguem a criança fora. Revista Consultor Jurídico, 2020.

Disponível em: https://bit.ly/34bwHDv. Acesso em: 30 jul. 2020.

UNESCO. Disinfodemic: Deciphering COVID-19

disinformation: Policy brief 1.2020. Disponível em:

https://bit.ly/2Yd5KLB. Acesso em: 30 jun. 2020.

WALDMAN, Ricardo Libel; NEVES, Marcelo Nogueira. Sociedade Da Informação: A Responsabilidade Na Internet E O Mau Uso Da Tecnologia, A Busca Pela Ética No Convívio Digital. Prim Facie, v. 19, n. 40, p. 01-28, abr. 2020. Disponível em:

https://bit.ly/2RrnaAD. Acesso em: 13 set. 2020. 
Mecanismos De Combate À Desinformação: Uma Análise À Luz Da Comissão...

Mechanisms To Combat Disinformation: An Analysis In The Light Of The Inter-American Commission On Human Rights

\author{
Beatriz Pereira Junqueira
}

Paulo Henrique de Souza Freitas

\begin{abstract}
Using qualitative research, the deductive approach method and bibliographic and documentary research techniques, the article aims to analyze the mechanisms to combat disinformation in the light of the recommendations of the Inter-American Commission on Human Rights and the tripartite test developed by the jurisprudence inter-American. It was concluded that false information is included in the scope of legal protection conferred to freedom of expression, since the requirement for veracity in information tends to degenerate into censorship of the right to freely express opinions, ideas and information; and the eventual criminalization of fake news, as well as the liability of providers, constitute extremely dangerous restrictions on freedom of expression and illegitimate, since they do not meet the basic requirements set by the tripartite test. Finally, it emerged that the recommendations made by the Inter-American Commission to national states are aimed at promoting positive measures such as media literacy, raising public awareness and encouraging fact-checking platforms, as they represent promising alternatives in combating disinformation while not imposing restrictions or suppressions on freedom of expression.
\end{abstract}

Keywords: Fake news. Freedom of expression. Media literacy. Awareness. Fact checking.

DOI: https://doi.org/ 10.22478/ufpb.1678-2593.2021v20n43.54652

Conteúdo sob licença Creative Commons: Attribuition-NonCommercial-NoDerivative 4.0 International (CC BY-NC-ND 4.0)

(cc)) EY-NC-ND 